\title{
Fabulous Awakenings: the Ethics of Metafiction in La vida es sueño by Calderón de la Barca and Some Tales from the Arabian Nights
}

\author{
Ana Elena GONZÁLEZ TREviÑo \\ Universidad Nacional Autónoma de México
}

\begin{abstract}
La manipulación de la realidad al estilo de La vida es sueño produce una estructura narrativa en planos asociada con la metaficción. Dicha estructura se puede encontrar también en varios cuentos de Las mil y una noches. Este ensayo busca describir y tipificar esta manipulación citando, además de la obra de Calderón, los cuentos "El durmiente despierto", "La historia del príncipe Camaralzamán y la princesa Budur" y “La historia de Nuredín Alí y Bedredín Hasán”. Si bien en la metaficción contemporánea es el autor quien usualmente manipula la realidad, en la obra de Calderón y en los cuentos citados es una figura de poder, natural o sobrenatural, la que interrumpe el curso normal de la acción. Se describe la dimensión ética del acto, así como las consecuencias de los tres tipos de despertar que viven las víctimas de esta interferencia.
\end{abstract}

PALABRAS CLAVE: metaficción, orientalismo, Calderón de la Barca, Las mil y una noches, estructura narrativa.

The manipulation of reality in the style of Calderón's Life is a Dream produces a narrative structure organized in planes related to metafiction. This structure may be found as well in stories from The Arabian Nights. This essay intends to describe and typify the aforementioned manipulation by referring to the tales of "The Sleeper Awakened", "The Story of Prince Camaralzaman" and "The Story of Nouredin Ali and Bedredin Hassan". Whereas in contemporary metafiction it is usually the author who manipulates reality, in Calderón's play and in these three tales it is a character endowed with power, either natural or supernatural, who interrupts the normal course of action to create a specific fantasy. The ethical dimension of this act, as well as the consequences of the three types of awakening experienced by the victims of the interference, are also dealt with.

KEY WORDS: metafiction, orientalism, Calderón de la Barca, Arabian Nights, narrative structure.

To Adam R.

Defined for practical purposes as fiction about fiction, metafiction goes against the grain of conventional aesthetics by conveying a sense of playful or even parodic 
self-awareness which stresses self-conscious artifice and artificiality within a literary work, instead of adhering to the old dictum, ars est celare artem (it is an art to conceal art), which calls for the concealment of rough edges in order to create the illusion of seamlessness (Mikics: 180). Since its nature appears to be contesting and defiant, metafiction has often aroused sympathy in our present-day context, amicable to all things rebellious; for this reason, it has often been assumed to be a postmodern phenomenon, frequently appearing in the innovative writings of authors such as John Barth and Donald Barthelme. Nevertheless, the device is an ancient one, making one of its first and most memorable appearances in Western fiction in the collection known as the Arabian Nights, published for the first time in English around 1709, after Galland's translation into French between 1704 and 1717 (Ross: 32).

One of the reasons why the Nights may have acquired such popularity at the time is because there was already an acute cultural receptiveness and predilection for this metafictional device, which had been often employed in early modern drama, particularly in what came to be described in Spain as baroque or Golden Age theater. The difference is that within an orientalist context, the effect of estrangement from reality could be enhanced through an association with otherness, an otherness in which the collapse of the boundaries between fiction and reality would seem more 'natural', and every narrative event could be readily called into question, regardless of its status. Whereas in postmodern fiction it is the narrator who establishes this ironic, self-conscious point of view, in the tales from the Arabian Nights the narrator of the frame-tale seems to be stable and straight-forward, completely engaged by her narration, leaving the, as it were, dirty job of subverting the ordinary course of life to some other character. It is usually some powerful entity, whether it be the sultan, a genie or a perie, a female genie, who exercises his or her power to interfere with the categories of fact and fiction in their victim's mind, and such is also the case, as we shall see, in Calderón de la Barca's La vida es sueño, which doubtless has much oriental influence. This interference or rather manipulation of reality allows the reader to perceive several narrative planes, which work within the edifying or didactic dimension of literature towards the unsettlement of the reader's context. Metafictional devices thus deliberately undermine the stability of representation, even when the ethical grounds for manipulation may be highly questionable.

Any sense of reality depends on a sense of temporal continuity which can only be experienced in the first person singular and which therefore lies at the core of selfhood. Should this sense of continuity be interrupted in any way, the sense of a cogent self would be seriously threatened, if not damaged beyond repair, and could even lead to mental alienation. Dreams and nightmares are a familiar experience of alienation from habitual reality. Recognized as such, they allow for a certain destabilizing of the categories of fact and fiction, a manageable loss of stability which may usually be kept within control. Upon awaking, it is relatively easy to allow the oneiric reality to vanish, and for the dreamer elastically to return to 'true' reality. Memory establishes a conceptual bridge with the last recalled state of vigil, which serves to preserve the integrity of the self. 
Memory, as a matter of fact, is one of the basic ingredients of the thing we call reality. It enables us to create a sense of identity by allowing us to tell the story of who we are. Such narratives purport to be selfhood in action, each episode furthering the illusion of an integrated self. The plausibility of our story will determine the degree of authority we have in the outside world, both through the reliability of our memory, and through our ability to achieve congruence between our story and the person we are perceived to be. The more plausible our story, the greater our authority, and vice versa: if our story is unlikely or implausible, we may lose credibility, but if it is totally outrageous, we will be called mad. The stories we tell about ourselves serve to define the way we transact with the world, what assets and what liabilities people can be led to expect from us, and how efficaciously we are able to stitch together "the discursive 'outside' with the 'internal' processes of subjectivity" (Barker: 386). We have seen, both in literature and life, tragic examples of distraught characters who risk losing all merely because of their insistence on the truth of a certain story that defies prevalent thought, like King Lear or Galileo, for example. What is taken for truth is a currency with an essentially social import, but we tend to forget its inevitably consensual nature. Failure to comply with that consensus leads to punishment, incarceration, torture and even death.

Plausibility is determined by the ability to differentiate between the representation of the outside world and wholly internal notions, the difference between objective perception and subjective conception. In the world of dreams, therefore, the reticent dreamer may want to test reality in order to assert the reliability of his or her perception. In the face of any experience which seems to break with the self's idea of continuity, he or she may be wary and ask for some kind of assurance, usually in the form of physical proof. Testing reality, or rather testing our perception of reality, is one way of establishing the grounds for making a truth claim. Metafictional texts in particular insist on the fact that no definite proof can be offered either way, throwing a veil of unreality on even the most habitual and trustworthy level of consciousness. ${ }^{1}$ In other words, 'life is but a dream'.

Such is the basic premise of one celebrated example, Calderón de la Barca's La vida es sueño (1636), usually translated into English as Life Is a Dream. It is the story of Prince Segismundo who has been kept a captive all his life on account of a disastrous prediction at his birth. His father, King Basilius, fearing deposition by his own son, ordered his imprisonment in a tower while making sure the prince remained unaware of his lineage and rank. The king's privileged social position both allows and entitles him to tamper with reality and to artificially create split versions of it in his son's mind. Notwithstanding, and in keeping with classical tragedy in the style of Oedipus Rex, such an action only contributes to the fulfillment of the oracle's prediction. King

\footnotetext{
1 'Reality testing' is a psychoanalytical concept developed by Freud in "A Metapsychological Supplement to the Theory of Dreams". For further information, see Jacob Arlow, "Fantasy, Memory, and Reality Testing", in Psychoanalytic Quarterly 38, (1969), 28-51, available in PEP, Psychoanalytic Electronic Publishing, A Fully Searchable Digital Archive of Classic Psychoanalytic Texts. http://www. pep-web.org/document.php?id=PAQ.038.0028A
} 
Basilius believes he has the perfect plan. He will let Segismundo reign for a day. If he turns out to be merciful and just, his true birthright will be revealed and the prince will be crowned; if, on the other hand, he turns out to be a tyrant as predicted, he will be returned to prison and persuaded to think that everything was just a dream. If such were the case, Basilius's nephew and niece will marry and inherit the crown. By creating a potentially fictional plane, Basilius purportedly wishes to protect both himself and his son, through the device of the secret trial, that is, a trial only he will be aware of. Nonetheless, the ultimate fulfillment of the oracle would make it appear that Basilius's power to create the illusion of reality was also limited, and what appeared to be a justified ethical choice loses some of its credibility.

The prince initially fails the test by succumbing to his own anger and resentment, so Basilius has him sent back to the tower; upon awaking, Segismundo concludes that, if his experience as king was only a dream, then everything must be so, and he opts for good behavior full of contrition and resignation. The raging prince becomes a philosopher-king, is ready to rule justly, and the play comes to an end.

Calderón's metafictional aesthetics is the standard for the baroque period, equivalent to Velázquez's painting within a painting in Las meninas, or Cervantes's play within a play in El retablo de las maravillas, or Shakespeare's Hamlet or A Midsummer's Night Dream. The two separate yet self-contained frameworks of fact and fiction serve as an artistic device that was popular at the time, and was usually employed to emphasize the transient and illusory quality of all reality. The recurring theme of el desengaño serves standard Christian moral purposes, which are on the one hand predictable and on the other, compatible with both gravitas and levitas, which means the tone could go from light-hearted frolicking to tragic inevitability. This is one of the reasons why it has been pointed out that La vida es sueño borrows the device from the Oriental Story of the Sleeper Awakened, which forms part of the Arabian Nights. Arturo Farinelli, who was the first to point out the connexion in his seminal study of the sources of Calderón entitled La vita é un sogno of 1916, also refers to other medieval sources, such as an exemplum from the collection of El conde Lucanor: "De commo la onrra deste mundo no es sinon commo suenno que passa" where the king and a drunken blacksmith temporarily exchange places. There is also a letter dated on 1556 by Luis Vives where he recalls the anecdote. Other early seventeenth-century playwrights like Agustín de Rojas (El viaje entretenido, 1603 and El natural desdichado) make use of the story. Yet another important source is the legend of Buddah and its Christian adaptation, Lope de Vega's Barlaam y Josafat, of 1612, which in turn is based on thirteenth-century stories from the Sendebar o Libro de los engannos et asayamientos de las mujeres and the Libro de los estados by the Infante don Juan Manuel. But by far, the favorite tale with which La vida es sueño has been compared is The Story of the Sleeper Awakened (Rodríguez Cuadros, n. p.). This story, which seems to coincide on several points with Calderón, is part of the Arabian Nights which was not translated into French until the early eighteenth century, but a version of it may have been available to Calderón via the Infante don Juan Manuel. 
Here is a summary. Grateful for the hospitality of a merchant called Abon Hassan, caliph Haroun al-Raschid gives him a sleeping drug and has him taken to his palace. Abon Hassan awakens in the caliph's bedroom. He cannot believe his eyes at first, so he proceeds to test reality by asking a lady to bite his finger so he can tell whether he is asleep or awake (ANE: 615). ${ }^{2}$ Needless to say, it passes the test. Once he has persuaded himself of the reality of what he is experiencing, he rules with justice and behaves exquisitely. The following morning, however, Abon Hassan is taken back home. His second awakening is very different from the first: he is totally unwilling to renounce to the idea that he is the Commander of the Believers, the sultan of Baghdad. He mercilessly beats his mother up and is soon declared mad and taken to a madhouse. After weeks of severe torture he accepts his diminished position, and is finally set free. But this is only the first part of the story. The second, more audacious and even subversive, is rarely brought up in relation to Calderón, and yet it reveals how the stratagem could be manipulated from both ends.

In the second part, Abon Hassan has been adopted by the caliph and married Nouzhatoul-aonadat, one of the ladies in waiting of Zobeide, the caliph's wife. The couple find themselves broke after a year of living beyond their means, and they resort to the strategy of feigning their own death, each in turn, in order to claim money for each other's funeral. What is remarkable about this part of the story is the role reversal between the merchant and the caliph. Whereas in the first part Haroun al-Raschid, just as King Basilius, had been the controlling agent, that is, the deus ex machina of the jest, in the second part Abon Hassan, notwithstanding his inferior rank and power, and relying entirely on his own wit and the generosity of Haroun al-Raschid, devices a stratagem to get what he wants without losing face, while additionally amusing the caliph. By becoming a kind of fool or jester for Haroun al-Raschid, Abon Hassan appropriates the power necessary to improvise a theatrical fiction, resulting both in the sultan's rejoicing and his own financial rescue.

Now, back to Calderón. The relationship between natural and supernatural agencies in La vida es sueño could be summarized as follows. While Basilius construes himself as the puppeteer or godlike figure who can manipulate reality to suit his whim, he is acting in accordance with a pronouncement derived from a supernatural agency: his own reading of his son's horoscope, and his own oracular interpretation of his wife's death at childbirth, the eclipse that occurred at the time, as well as other fatidic signs of disaster. In this sense, Basilius is enslaved to astrology, while paradoxically expecting his son to be strong enough to prove his evil star wrong. This has an effect on the vertical hierarchies established in the play. Power relations are irreversible: Segismundo, the man-beast, is at the nethermost level; then Basilius, as controlling agent, feels morally entitled to manipulate his son's destiny, but God through the supernatural agency of the oracle, is at the topmost level of the scale and holds absolute control over them all.

\footnotetext{
${ }^{2}$ For the sake of convenience, I will be using the 1709 English translation. All subsequent references to the anonymous Arabian Nights Entertainments will be abbreviated as ANE.
} 
Contrastingly, in The Sleeper Awakened, power relations between the sultan and Abon Hassan are relatively even in the balance. Otto María Carpeaux has proposed that in all baroque examples of this metafictional device it is the lowly man, the homo ex plebe who suffers the brunt of the attack (Carpeaux: 219). And yet in this example, the homo ex plebe constitutes the fundamental otherness which grandeur must call its own if it is to achieve its end. After all, Haroun al-Raschid had to disguise himself as a commoner in order to enter the world of Abon Hassan. Abon Hassan was in turn dressed and treated as sultan, only to return to his original attire and living circumstances later. The only way in which Abon Hassan could supersede Haroun al-Raschid was by appropriating the code of a realm beyond the caliph's power, i.e. the realm of death. Disguises serve to reverse identities, and death is here, in a ludic sense, another type of disguise. Death can be feigned, at least for a while, and this is enough for Abon Hassan to exact the desired behavior from the caliph. The adoption of one disguise or another, is an ethical choice that relies on laughter as its most powerful justification.

There are at least two other stories in the Arabian Nights where characters are transported out of their habitual sphere, in the context of dreams, in order to fulfill the mysterious or transcendent intentions of supernatural creatures. In both of them, it is not the power to rule that is at stake, but the fulfillment of love. The stories are The Story of Prince Camaralzaman and The Story of Nouredin Ali and Bedredin Hassan. I will look at each of them in turn in order to illustrate this point.

Prince Camaralzaman, only son and heir of the sultanate of the Islands of the Children of Khaledan, off the coast of Persia, refused to marry, disregarding his father's commands. After three years of refusals, the sultan ran out of patience and had his son locked up in a tower, pretty much like Segismundo's, with only one slave to attend him (ANE: 363). A fairy or perie happened to live in the same tower, and when she saw the handsome prince, she was amazed at his beauty and she pitied him for his loss of liberty. On that very night she encountered a genie — peries and genies were usually at war with each other, peries being generally more powerful — who claimed there was a princess in China who rivaled Camaralzaman in beauty. She also refused to marry and was kept prisoner in an apartment in one of her father's seven palaces (ANE: 366).

The perie and the genie quarrel because they cannot agree about who is the more beautiful of the two, the prince or the princess. The genie then flies to China and back, bringing along with him the sleeping princess, whom he lays quietly beside Camaralzaman. The result of the experiment, regardless of the dispute, is that Camaralzaman and Princess Peri Banou fall violently in love with each other, and exchange rings, each unbeknownst to the other. The following morning, they each awaken in their own chambers, and literally go mad with longing. What was achieved through the magical agency of the perie and the genie, must now be repeated by entirely human means, so it takes them many years to reunite. In the end they finally do, and they have many other adventures which are not relevant here. In any case, the rings that were exchanged that night introduce an additional element to our study: having material proof, in this case, an object that serves to reassure the characters about the reality of their implausible 
memory. The point here is that peries and genii are beyond the realm of conventional "human" ethics, and the absence of any solid justification for their actions places them beyond any accountability understandable to human beings.

The same device is employed, but even more dramatically, in The Story of Nuredin Ali and Bedredin Hassan. This is a highly complex story, rich in variety and twists in the plot. At one point, young Bedredin Hassan has been left completely destitute and falls asleep in a cemetery. Just as Princess Peri Banou, he is transported by a genie to the wedding chamber of the bride he was destined to marry according to a promise his father and hers had made in their early youth. As a result, his wife of one night becomes pregnant while Bedredin is flown away to yet another city by the genie, without any apparent justification, other than the genie's own entertainment. Bedredin does not go mad, interestingly, even when he awakens surrounded by people who accuse him of madness. His wife, back in the other city, experiences something similar. The couple in this story is very calm about the extraordinary experience of the night, as if they had more than willingly succumbed to the desires of the genii, which, on the other hand, eerily fulfills the promise of both their fathers. It is true that Bedredin is somewhat vexed at what is going on, but he seems to accept his new situation with an easy heart. His extraordinary beauty seems to open all doors for him, and so he does not seem to be an antagonist to fate. Yet, he will remain at least partly puzzled for ten years, when he finally encounters physical proof of what had seemed to be only a dream: the princess was made pregnant on their wedding night, and gave birth to a son, Agib, whom Bedredin encounters and unconsciously recognizes.

In these two stories, the magical, fairy tale tone, serves to enhance the inevitability of fate even in the most improbable circumstances. And if in La vida es sueño and The Sleeper Awakened it was mostly the rulers or governors who could play with and manipulate their underlings, here it is the genii and fairies (or peries) who serve as ministers of fate. In the former cases, the controlling framework is conceived as part of their prerogative as rulers, or jesters to the rulers, whereas in the second, it is a question of supernatural powers enabling what was destined to be, through the metafictional device of manipulating reality, however unethical it may appear to be.

There are two fantasy topoi which have come into action here: being king for a day, in a 'prince-and-the-pauper' sort of way, and the fantasy of twin souls, being joined against all odds (Marzolph and Van Leeuwen I: 393). The glow of the miraculous belongs to both kinds, and yet, it seems somehow more appropriate to relate La vida es sueño to the story of Camaralzaman, and that of Bedredin Hassan because of the tone. The story of The Sleeper Awakened has a jocund, even hilarious tone, which cannot be overlooked, and which seems hardly appropriate to compare with the solemn, even tragic tone of La vida es sueño. On the other hand, the dreamlike atmosphere of Camaralzaman and Bedredin Hassan is more akin to Calderón's play, even when the manipulating agents are supernatural and cannot be held accountable on human terms.

In all four cases, there are three types of awakening, which occur in exactly the same pattern. The first awakening is an upgrading one which produces initial surprise 
because highly unexpected. It is brought about by some superior power: a monarch who transgresses habitual ethical codes and serves himself of a drug, herb or potion that may induce sleep at a convenient time, and subordinates who can carry the sleeping body of his victim to the new place; or a genie or fairy who can fly through the air and transport sleeping bodies without much effort. The experience feels alien and dreamlike to the victim, but since it offers the dreamer a higher, more evolved or joyful version of himself, it easily becomes a desirable state.

The second awakening is always downgrading, and to the victim it may feel like a hangover or even like the expulsion from Paradise: a powerful agent, whether it be the king or sultan, or the fairies and genies, return the dreamer to his or her original context. Since it entails loss and disappointment, the second awakening inevitably makes the character's former life seem no longer palatable. It is also dreamlike, but rather nightmarish. It usually leads to severe fits of anger and sometimes madness. At this point the character feels like he or she no longer belongs to the place where he used to feel safe. The inability to discern the exact place where the dreamers belong may have tragic consequences, like the flogging of Abon Hassan (which is the only disquieting, non-festive episode in The Sleeper Awakened) or the terrible suffering of Camaralzaman and Peri Banou which leads to their torture and imprisonment. When there is material proof, at this point it will usually be discredited and it will only serve to drive the character further down in his or her loss of credibility.

The third awakening is upgrading again, but this time the experience is a sobering one, and it entails a psychological growth on the part of the dreamer. It may be that the character, fearing for his physical and mental well-being, refuses to accept it as real, or does so with extreme caution, until gradually, the sense of continuity is re-established and the character finally calls the new and better place his own. That is when he is considered to be ready for greatness.

Another interesting notion is the fact that, conceptually, Segismundo's tower is as far from the throne as China is from Persia. The implication is that social hierarchy can draw human beings as far apart as geographical distance, but also that both are equally surmountable. These tales are about social mobility. No matter how far from the throne the heir is, no matter how distant twin souls may be, life is bountiful and flexible enough to afford all the necessary bridges to surmount the distance.

There are different moral lessons to be drawn from this. Calderón's philosophical play proclaims a lesson akin to the emblematic Wheel of Fortune: one minute you are up, the next, you have inexplicably come down. If you develop attachments to either position, you will inevitably suffer. If you don't, you are on the safe side, and, from a Christian point of view, by avoiding worldly attachments you will be closer to heaven and salvation. There prevails a serious, ascetic tone.

On the other hand, the stories from the Arabian Nights present a different picture. Possible destinies are so vast and varied, that even the most fabulous or far-fetched desires may come true. The spirit world may be having fun at the expense of human beings, but human beings always get the better part of the deal. And if circumstances 
defy belief, that's even better. In the end, there is always a sense of joyous growth and achievement, no matter what price was paid for it.

\section{Works cited}

Arabian Nights' Entertainments. 1998. Ed. and intro. Robert L. MACK. Oxford: University Press. (1 ${ }^{\text {st }}$ ed. 1706-21.)

Ballaster, Ros. 2005. Fabulous Orients: Fictions of the East in England, 1662-1785. Oxford: University Press.

BARKer, Chris. 2000. Cultural Studies, Theory and Practice. London: Sage.

BARTRA, Roger. El salvaje artificial. México: UNAM.

CALDERÓN DE LA BARCA, Pedro. 2002. La vida es sueño. Ed. Enrique Rull. Barcelona: Ediciones de Bolsillo.

CArPeAuX, Otto María. 2007. “La Torre”. Realidad: Revista de Ideas. Buenos Aires: Renacimiento. Pp. 214-228.

FARINELLII, Arturo. 1916. La vita é un sogno. Torino: Bocca Editori.

Libro de las mil y una noches. 1993. Trad., introd. y notas Rafael CANSINOS ASSÉNS. Madrid: Aguilar.

MARZOLPH, Ulrich and Richard VAN LEEUWEN. 2004. The Arabian Nights Encyclopedia. Santa Barbara, California: ABC-Clio. 2 vols.

RODRÍGUEZ CUADROS, Evangelina. La vida es sueño: obra paradigmática (Cervantes Virtual http://www.cervantesvirtual.com/bib_autor/Calderon/vidasueno.shtml). 